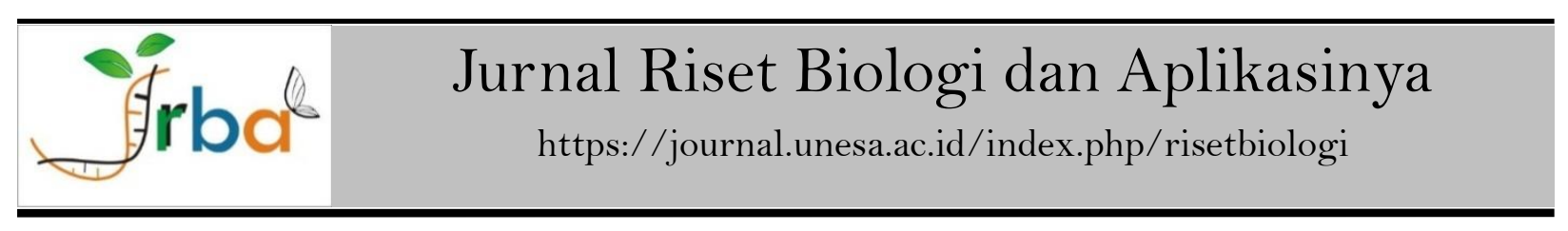

\title{
Diversity and Community Structure of Dragonfly and Damselfly (Odonata) at the Selorejo Waterfall Area, Ponorogo Regency, East Java Indonesia
}

\author{
Muhamad Azmi Dwi Susanto*, Siti Zulaikha \\ Biology Departement, Faculty of Science and Technology, UIN Sunan Ampel Surabaya \\ Jln. Ahmad Yani No.117, Jemur Wonosari, Wonocolo District, Surabaya 60237, East Java, Indonesia \\ *Corresponding Author: \\ e-mail: Muhammadazmidwi@gmail.com
}

\section{Article History \\ Received : 20 Februari 2021 \\ Revised : 14 March 2021 \\ Approved : 22 March 2021 \\ Published : 31 March 2021}

\section{Keywords}

Diversity; Community Structure; Odonata; Microclimate; Vegetation

\begin{abstract}
Selorejo Waterfall is a natural tourism area that is quite far from downtown Ponorogo and directly adjacent to the Gunung Sigogor Nature Reserve. Hence, this area has the potential as a natural habitat for dragonfly and damselfly. The presence of dragonfly and damselfly species is determined by the type of habitat, canopy conditions, vegetation diversity, and the microclimate that exists in a location. This study aimed to determine the diversity of dragonfly and damselfly and to determine the community structure of dragonflies in Selorejo Waterfall. The sampling method was Visual Day Flying. The results of research conducted in two streams showed that there were 12 species from 6 families with a total of 230 individuals. The value of species diversity at this location is $H^{\prime}=2.05$. In the community structure at the Selorejo Waterfall dragonfly, there are differences in the number of species and individuals in the two streams in Selorejo Waterfall Area. The large stream, eight species from four families, 151 individuals in total. Meanwhile, in small stream, there were nine species from six families, 79 individuals in total. The differences in the number of species and individual dragonflies in the two streams at Selorejo Waterfall can be used to describe the diversity and structure of the Odonata community in the area.
\end{abstract}

How to cite: Susanto, M.A.D \& Zulaikha, S. (2021). Diversity and Community Structure of Dragonfly and Damselfly (Odonata) at the Selorejo Waterfall Area, Ponorogo Regency, East Java Indonesia. Jurnal Riset Biologi dan Aplikasinya, 3(1): 30-37. DOI: https://doi.org/10.26740/jrba.v3n1.p30-37.

\section{INTRODUCTION}

Selorejo Waterfall is a natural tourist area located in Ngebel District, Ponorogo Regency, East Java, Indonesia. The location of Selorejo Waterfall is quite far from the center of Ponorogo City with a quite difficult road access and this tourist location is directly adjacent to the Gunung Sigogor Nature Reserve. This makes the environmental conditions at Selorejo Waterfall still natural with little environmental pollution. The natural environmental conditions of Selorejo Waterfall have the potential as a natural habitat for various types of insects, especially dragonfly.

Dragonfly are medium-sized flying insects with attractive body colors and wings. The body structure of dragonfly consists of three parts, namely Cephal (head), thorax (chest), and abdomen (stomach). Dragonfly have slender bodies with two pairs of wings and have mesh veins. Besides, dragonfly also has an antenna, a chewing-type mouth apparatus, and large compound eyes (Hanum et al., 2013). In scientific classification, dragonfly is included in the Odonata Order, this is because dragonfly has toothed-jaws found in the lower labium (Rizal \& Hadi, 2015).

In general, Odonata is classified into two Suborders, namely Suborder Anisoptera known as dragonfly, and Suborder Zygoptera is known as damselfly. These two suborders have striking differences, including the distance between the two compound eyes. In the dragonfly, it looks very closely or there is almost no distance between the two compound eyes, while in the damselflies there is a visible distance between the two compound eyes (Soendjoto, 2016). Suborder Anisoptera has wide wings, large body stature with high flight ability. 
Whereas in the Suborder Zygoptera has a small body stature, the front, and rear wings are of the same size and have weak flying abilities (Rahmawati et al., 2019).

Dragonfly are insects that undergo imperfect metamorphosis. There are three phases in the dragonfly life cycle namely the egg, nymph and adult phases. In the egg and nymph stages of dragonfly live aquatically (Bried \& Hinchliffe, 2018), while the adult phase is terrestrial (Laily et al., 2018). As adults, dragonfly will breed around the aquatic environment and female dragonfly will lay their eggs among water plants (Setiyono et al., 2017). The existence and distribution of dragonfly species in a location is determined by many factors, including the type of habitat, canopy conditions, diversity of vegetation, and microclimate. Therefore, this study aimed to determine the diversity of dragonfly species and to determine the community structure of dragonfly and damselfly in Selorejo Waterfall, Ponorogo Regency, East Java, Indonesia.

\section{MATERIALS AND METHODS}

\section{Time and Location Study}

This research was conducted in JanuaryFebruary 2021 in the Selorejo Waterfall area, Toyomerto Hamlet, Ngebel District, Ponorogo Regency, East Java, Indonesia. This research was conducted during the active hours of dragonfly, namely 09.00-13.00 by tracing two streams of water in the Selorejo Waterfall area, namely Large stream and Small Stream.

\section{Tools and materials of Reseach}

The tools and materials used in the research are stationery, GPS (Global Positioning System), watches, insect nets, cameras, and thermohigrometers.

\section{Data Collection}

Sampling was conducted using the Visual Day Flaying method by following the transect paths along the large stream and small stream of Selorejo Waterfall. The Visual Day Flaying method was carried out to record all species along with the number of individuals found during the study. In addition to recording the number of species and individuals, this study also recorded microclimate data, namely temperature (C), humidity (\%), and light intensity (lx). In the identification process using the dragonfly identification book Orr (2005), Pamungkas (2016), and Setiyono et al., (2017).

\section{Data Analysis}

The data obtained in the study will be analyzed using the Shannon-Wiener Diversity Index $\left(H^{\prime}\right)$ (Azmi et al., 2006) and Relative Abundance (RA) (Suaskara \& Joni, 2020). The following is the formula for each analysis:

Shannon-Wiener Diversity Index:

$$
H^{\prime}=\sum\left(\frac{n i}{N} \operatorname{In} \frac{n i}{N}\right)
$$

Relative Abundance Index:

$$
R A=\frac{n i}{N} \times 100 \%
$$

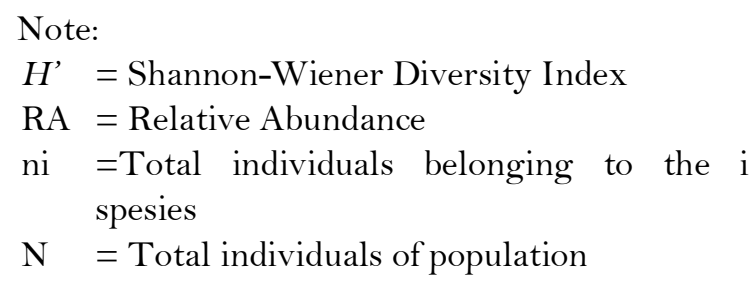

\section{RESULT AND DISCUSSION}

Based on the carried-out inventory at the Selorejo Waterfall Area, the results were 12 species from six families consisting of four species of damselfly and eight species of dragonfly. The number of individuals found was 230 individuals, of which 151 individuals were found in the Large Stream and 79 individuals were found in the Small Stream.

The diversity index value of dragonfly and damselfly in the Selorejo Waterfall area is $H^{\prime}=2.05$ (Figure 1), this indicated that the diversity value was classified as medium. This statement is supported by Hartika et al. (2017), which states that if the Shannon-Wienner diversity index value $H^{\prime}=$ 1.5 to 3.5 then the diversity value is medium. This showed that the environmental conditions in the Selorejo Waterfall Area are good enough to support the natural habitat of dragonflies. The diversity value of dragonflies in Selorejo Waterfall has a higher value than the diversity value of dragonflies in the tourist area of Kakek Bodo Waterfall, Pasuruan Regency, namely $H^{\prime}=1.78$ (Abdillah et al., 2018; Abdillah et al., 2019). Meanwhile, the diversity value of dragonflies in Selorejo Waterfall is lower than the diversity value of dragonflies (Odonata) in the secondary forest on the riverbank of Kali, Kali Village, Minahasa Regency, North Sulawesi, which is $H^{\prime}=2.56$ (Lino et al., 2019). 
The value of dragonfly species diversity at the Small Stream area, namely $\mathrm{H}^{\prime}=1.93$, was higher than the dragonfly species diversity value at the Large stream location, namely $\mathrm{H}^{\prime}=1.69$. The presence and number of individual dragonfly species found in the two waterways are different because the two streams have different environmental conditions, habitat types, canopy, and vegetation conditions. According to (Herlambang et al., 2016), the main factors that make differences in dragonfly species diversity in each place are factors of food resources, habitat and other factors. Several other factors are temperature, humidity, light intensity and availability of food.

Temperature and humidity affect plants and animals, especially small insects as the main food of dragonflies. In addition, temperature also determines the activity of dragonflies in finding a place to rest, flight time and breeding time (Corbet, 1962). Light intensity is an abiotic factor that affects the activity of a dragonfly somewhere. This is because the light intensity affects dragonfly activities such as sunbathing and foraging for food. At optimal light intensity, dragonflies will be used for sunbathing and foraging, whereas if the light intensity is too low and too high, dragonflies will be spent resting and shelter (Corbet, 1962).

Vegetation and canopy conditions in a place affect the existence of dragonfly species because the dragonflies need vegetation such as sub-layer plants to lay their eggs when reproducing and can be used for perches (Nugrahani et al., 2014). Besides, dragonfly larvae need vegetation on river banks to find food and to protect themselves from predators. In adult dragonflies, the vegetation on the banks of the river is used for resting and sunbathing (Silva et al., 2010). As for the canopy, several types of dragonflies are used to protect from the high intensity of sunlight (Nugrahani et al., 2014).

A microclimate is an important factor in providing habitat that supports the sustainability of the dragonfly life cycle (Abdillah et al., 2018). Microclimate data, showed the temperature and light intensity at small stream $\left(26.5^{\circ} \mathrm{C}\right.$ and 32767 $\mathrm{lx})$ lower than larger stream $\left(28.4^{\circ} \mathrm{C}\right.$ and $\left.17488 \mathrm{~lx}\right)$, Meanwhile, the humidity at Small Stream (75.0 C) has a higher value than the large stream (75.0\%) (Table 2). The thinner canopy at the Large stream makes the light intensity higher and will affect the air temperature at the location. Meanwhile, the slightly denser canopy conditions and the presence of many trees on the edge of the small stream, which cause an inhibition of the rate of air temperature and sunlight intensity so that the humidity value in this location has a higher value.

The location of the large stream was the main water stream from Selorejo Waterfall. A large stream was $\pm 3 \mathrm{~m}$ wide and $\pm 0.5 \mathrm{~m}$ deep with many large rocks in the middle. The edge of a large stream is dominated by herbaceous plants like a Cyperus rotundus (Pocacea Family), which also has an open canopy with few trees. With the conditions of vegetation and an open canopy, this stream was a suitable habitat for several dragonfly species to forage and roost. At this location, eight species were found with a total of 151 individuals, which belong to four families, namely the Euphaeaidae, Calopterygidae, Gomphidae, and Libellulidae families. At this location, it is dominated by the

Table 1. Dragonfly and Damselfly, Relative Abundance and Conservation Status

\begin{tabular}{|c|c|c|c|c|}
\hline \multirow{2}{*}{$\begin{array}{c}\text { Suborder \& } \\
\text { Family }\end{array}$} & \multirow{2}{*}{ Species } & \multicolumn{2}{|c|}{ Relative Abundance (\%) } & \multirow{2}{*}{$\begin{array}{c}\text { Conservation } \\
\text { Status }\end{array}$} \\
\hline & & Large stream & Small Stream & \\
\hline \multicolumn{5}{|l|}{ Zygoptera } \\
\hline Euphaeaidae & Euphaea variegata & 13.91 & 7.59 & $\mathrm{LC}$ \\
\hline Calopterygidae & Vestalis luctuosa & 22.52 & 18.99 & $\mathrm{LC}$ \\
\hline Clorocyphidae & Rhinocypha anisoptera & 0.00 & 16.46 & $\mathrm{LC}$ \\
\hline Platycnemididae & Coeliccia membranipes & 0.00 & 22.78 & $\mathrm{LC}$ \\
\hline \multicolumn{5}{|l|}{ Anisoptera } \\
\hline Gomphidae & Nepogomphus fruhstorferi & 0.66 & 2.53 & NT \\
\hline \multirow[t]{7}{*}{ Libellulidae } & Diplacodes trivialis & 0.66 & 0.00 & $\mathrm{LC}$ \\
\hline & Orthetrum glaucum & 9.93 & 15.19 & $\mathrm{LC}$ \\
\hline & Orthetrum pruinosum & 11.26 & 12.66 & $\mathrm{LC}$ \\
\hline & Orthetrum sabina & 5.96 & 0.00 & $\mathrm{LC}$ \\
\hline & Pantala flavescens & 35.10 & 0.00 & $\mathrm{LC}$ \\
\hline & Trithemis festiva & 0.00 & 1.27 & $\mathrm{LC}$ \\
\hline & Zygonyx ida & 0.00 & 2.53 & $\mathrm{LC}$ \\
\hline
\end{tabular}

Note: Least Concern (LC), Near Threatened (NT). Source: Dow, 2019a, 2019b; Gunther, 2019; Dow, 2019c, 2020a; Subramanian, 2020; Dow, 2009; Sharma, 2010; Mitra, 2020; Boudot et al., 2016; Dow, 2020b, 2020 


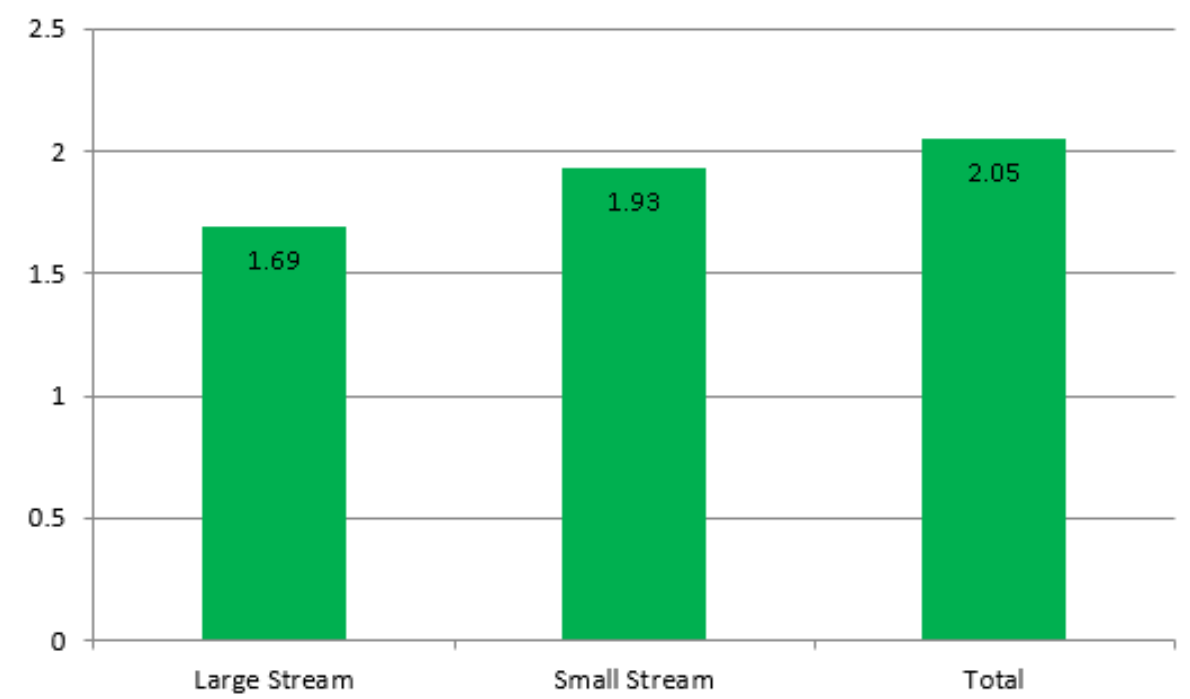

Figure 1. Diversity Index of Shannon-Wiener

Table 2. Abiotic Factors in Selorejo Waterfall Area

\begin{tabular}{llll}
\hline Location & $\begin{array}{l}\text { Air temperature } \\
(\mathrm{C})\end{array}$ & Humidity (\%) & Light intensity (lx) \\
\hline Large Stream & 28.4 & 74.6 & 32767 \\
Small Stream & 26.5 & 75.0 & 17488 \\
\hline
\end{tabular}

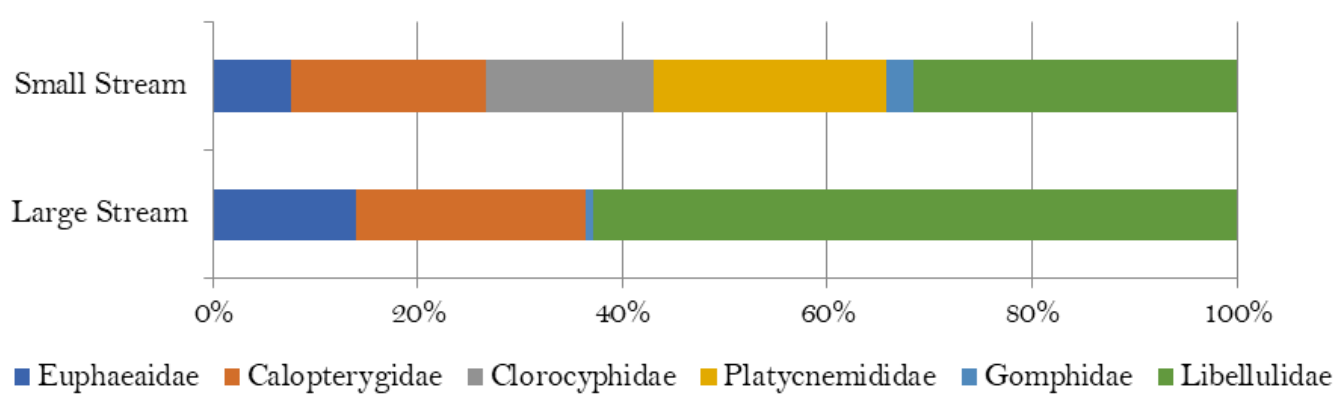

Figure 2. Family Composition of Dragonfly and Damselfly at the Selorejo Waterfall

Libellulidae family with relative abundance a value of $62.91 \%$, dragonfly members of this family are very commonly seen in various places (Setiyono et al., 2017).

There are three species found in the Large stream and not found in the small stream, namely Diplacodes trivialis, Orthetrum sabina and Pantala flavescens. The three species are only found in Large Stream because this stream has an open canopy habitat type. The Diplacodes trivialis species are often found perching on rocks in areas with open canopies, this species is often found flying low above the ground and is often found in rice fields and bushes (Pamungkas, 2016). Orthetrum sabina species are often found perching on logs and grass, this species is a cannibal dragonfly because it is often found preying on other dragonflies (Setiyono et al., 2017). Orthetrum sabina species can be found in a variety of habitats and breed in waters with slow to nonflowing flows (Pamungkas, 2016). Pantala flavescens species are often found in flying conditions in open areas (Setiyono et al., 2017), this species has long distance migration capabilities. Pantala flavescens species are often found in coastal areas, open areas, tropical areas and areas with temperate climates (Low et al., 2017).

The location of the Small Stream is a water Stream formed from the branching of the Selorejo Waterfall; this Stream has a width of $\pm 0.7 \mathrm{~m}$ with a depth of $\pm 0.3 \mathrm{~m}$ with a calm water Stream. Aliran 
Kecil has a slightly closed canopy dominated by shrubs and many trees on the banks of the stream. At this location, 9 species were found with a total of 79 individuals, which belong to 6 families, namely the Euphaeaidae, Calopterygidae, Clorocyphida, Platycnemididae, Gomphidae and Libellulidae families.

There are four species found only in small streams, namely Rhinocypha anisoptera, Coeliccia membranipes, Trithemis festiva and Zygonyx ida. Species Rhinocypha anisoptera and Coeliccia membranipes were only found in small stream sites because this location has a lower temperature and higher humidity value than Large Stream with a value of $26.5 \mathrm{C}$ and $75.0 \%$, both of these species tend to prefer habitats that have a closed canopy with relatively high humidity. Meanwhile, the Trithemis festiva and Zygonyx ida species can be found in various types of habitats, because dragonflies, which are included in the Anisoptera suborder, have high flight abilities. In the Rhinocypha anisoptera species found in forest rivers with dense canopies (Abdillah \& Lupiyaningdyah, 2021), Coeliccia membranipes species can be found in habitats with dense canopies and high humidity (Setiyono et al., 2017). Trithemis festiva species can be found in rivers with strong currents, while Zygonyx $i d a$ is often found in forests on rocky rivers (Pamungkas, 2016).

The Pantala flavescens species (Figure 3 ) is a dragonfly species that has the highest relative abundance value at Large stream locations with a value of $35.10 \%$ (Table 1). The Pantala flavescens species is included in the Anisoptera Suborder, this species was found in the large Stream observation sites with the highest number of 53 individuals. This species is characterized by the male, the upper eye is red and gray on the bottom. This species has a predominantly orange color on the thoracic and orange brown on the abdomen (Pamungkas, 2016). There is a black line on the top of the abdomen with a line that is getting thicker towards the end of the abdomen. Whereas females have a body that is dominated by a pale-yellow color with lower eyes gray and pale pink at the top (Setiyono et al, 2017).

The Pantala flavescens species is a type of migratory dragonfly that has the ability to migrate up to $18,000 \mathrm{~km}$ (Hobson et al., 2012). This dragonfly is often found in groups with hundreds of individuals. In this study, the Pantala flavescens dragonfly was not found at small Stream locations, this species was only seen in large Streams. This is due to differences in the canopy and vegetation of the two streams, in large streams that have open canopies and vegetation dominated by herbaceous vegetation so that this location becomes the right habitat for the Pantala flavescens species. This is supported by Pamungkas (2016), which states that the Pantala flavescens dragonfly is often found in open areas and is often found flying far from aquatic habitats.

The results of the relative abundance showed that the Coeliccia membranipes species (Figure 4) was the damselfly species which had the highest relative abundance value at small Stream locations with a value of $22.78 \%$ (Table 1 ). The Coeliccia membranipes damselfly is included in the Platycnemididae Family, this family has a body size ranging from small to medium with the main characteristic of having narrow wings with slightly open nets. This

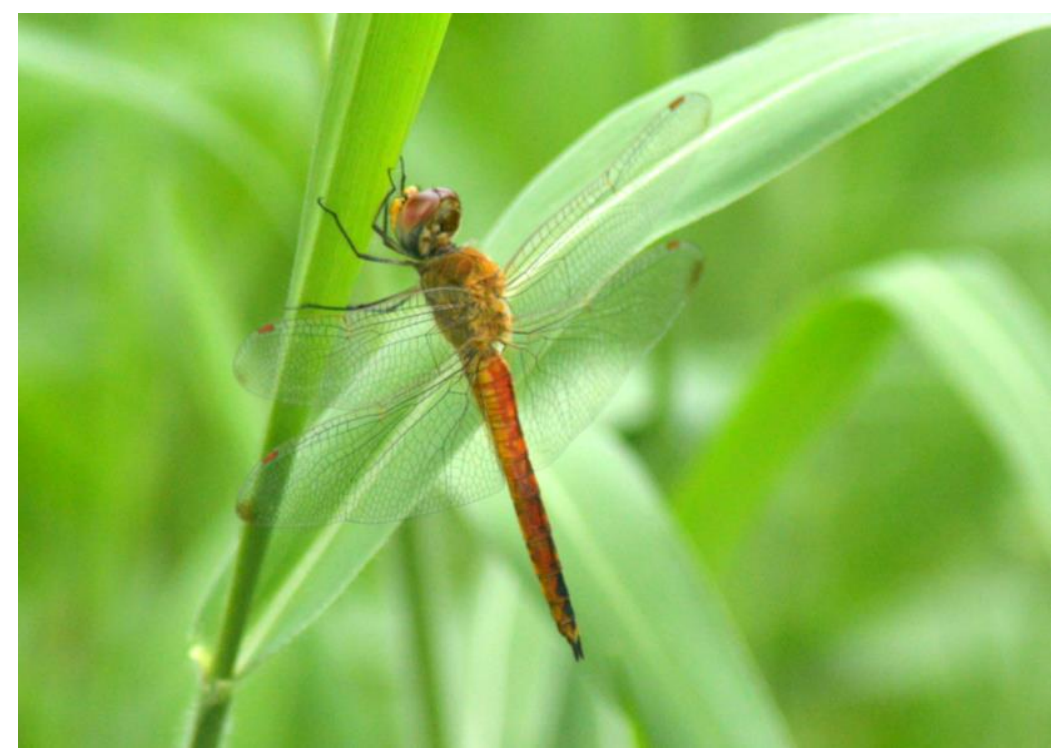

Figure 3. Pantala flavescens 


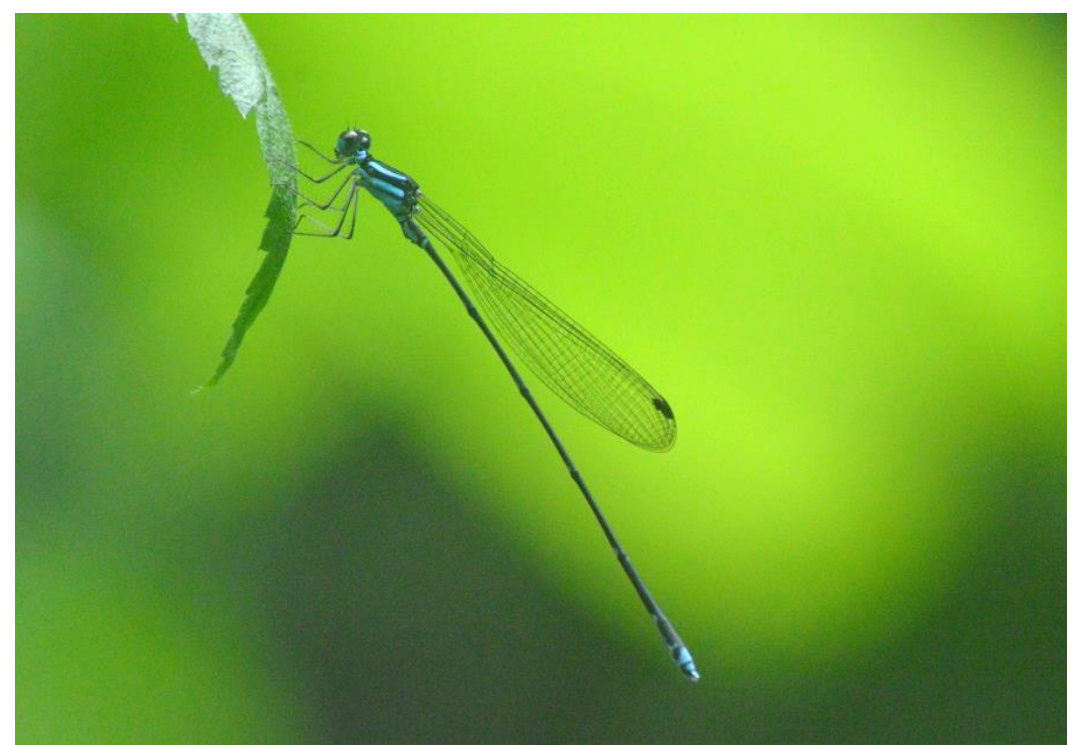

Figure 4. Coeliccia membranipes

family has features that are almost similar to Family Coenagrionidae (Kalkman \& Orr, 2015), but the wing tips can be different, namely the wing tips of Family Coenagrionidae are more rounded (Setiyono et al., 2017).

Coeliccia membranipes is found in small Stream observation sites with the highest number of individuals, namely 18 individuals. In the male Coeliccia membranipes species, the upper eye is black and blue on the bottom. Has a dominant blue color on the thorax with 2 black stripes on the upper thorax. The abdomen is dominated by black with $\mathrm{S} 1$ blue, $\mathrm{S} 2$ black blue, S9 blue slightly black, and S10 blue (Setiyono et al, 2017). Females have the same features as males but on the thorax and legs are yellow (Pamungkas, 2016).

In this study, the Coeliccia membranipes damselfly was only found in small Stream locations. This is because the small stream where this species is found has a closed canopy and the vegetation is dominated by shrubs, so this location is the right habitat for the Coeliccia membranipes species. Meanwhile, in large Stream locations, Coeliccia membranipes species were not found because the location has an open canopy which is not suitable for the habitat of the Coeliccia membranipes species. This statement is supported by Setiyono et al., (2017), which states that the damselfly Coeliccia membranipes can be found in places with dense canopy and high humidity.

\section{CONCLUSION}

Based on this study, it can be concluded that there were 12 species of dragonflies with a total of 230 individuals in the Selorejo Waterfall Area.
Relative abundance results indicate that the Pantala flavescens species is the highest species in the Big Stream area with a value of $35.10 \%$, and the Coeliccia membranipes species is the highest species in the Small Stream area with a value of $22.78 \%$. The index of species diversity at the Large stream location has a value of $\mathrm{H}^{\prime}=1.69$ and at the Small Stream location it is $\mathrm{H}^{\prime}=1.93$. The total value of the species diversity index in the Selorejo Waterfall Area is $\mathrm{H}^{\prime}=2.05$. New ideas are developed which are the essence of the research findings.

\section{ACKNOWLEDGEMENT}

The authors would like to thank you to the family of KUTRIK entomology study group and BBKSDA RKW o6 Ponorogo. We also thank M. Muhibbuddin Abdillah that helps in species identification and writing process.

\section{REFERENCES}

Abdillah, M., Alifuddin, F., \& Nur, F. (2018). Diversitas Odonata dan Peranannya Sebagai Indikator Air di Kawasan Wisata Air Terjun Kakek Bodo Kecamatan Prigen Kabupaten Pasuruan Abstrak. Seminar Nasional Biologi - Universitas Negeri Semarang "Eksplorasi Keanekaragaman Hayati Sebagi Upaya Konservasi Di Era Disrupsi," November 2018, 322328.

Abdillah, M. M., Prakarsa, T. B. P., \& Tyastirin, E. (2019). Odonata Diversity at Sumber Clangap and Sumber Mangli Puncu Village Sub District of Puncu District of Kediri. Jurnal Biodjati, 4(2), 236-243. https://doi.org/10.15575/biodjati.v4i2.4823.

Abdillah, M. M., \& Lupiyaningdyah, P. (2021). Distribution ,Characteristic and Behavior of Rhinocypha anisoptera Selys Distribution, Characteristic and Behavior of Rhinocypha anisoptera Selys, 1879 (ODONATA: ZTGOPTERA: East Java is a large province in Java. 
Zoologies Indonesia, 29(2)

Azmi, W. ., Julia, J., \& Amirrudin, A. (2006). Diversity and distribution of dragonflies (insecta: odonata) in sekayu recreational forest, terengganu a. wahizatulafzan, j. julia, a. amirrudin. Journal of Sustainability Science and Management, 1(2), 97-106.

Bried, Jason. T \& Hinchliffe, Robert. P. 2018. Improving Taxonomic Resolution In Large-Scale Freshwater Biodiversity Monitoring: An Example Using Wetlands And Odonata. Insect Conservation and Diversity. $1(1), \quad 1-9$. https://doi.org/10.1111/icad.12323.

Boudot, J.-P., Clausnitzer, V., Samraoui, B., Suhling, F., Dijkstra, K.-D.B., Schneider, W. \& Paulson, D.R. 2016. Pantala flavescens. The IUCN Red List of Threatened Species 2016: e.T59971A65818523. https://dx.doi.org/10.2305/IUCN.UK.20163.RLTS.T59971A65818523.en. Downloaded on 10 February 2021.

Corbet, P. S. (1962). Biology of Odonata. Annual review of entomology, 25(1), 189-217. https://doi.org/10.1146/annurev.en.25.010180.0012 01.

Dow, R.A. 2009. Orthetrum glaucum. The IUCN Red List of Threatened Species 2009: e.T163780A5650496. https://dx.doi.org/10.2305/IUCN.UK.20092.RLTS.T163780A5650496.en. Downloaded on 10 February 2021.

Dow, R.A. 2019a. Euphaea variegata. The IUCN Red List of Threatened 2019: e.T122209669A122209989.

https://dx.doi.org/10.2305/IUCN.UK.20192.RLTS.T122209669A122209989.en. Downloaded on 10 February 2021.

Dow, R.A. 2019b. Vestalis luctuosa. The IUCN Red List of Threatened Species 2019: e.T163807A137392306. https://dx.doi.org/10.2305/IUCN.UK.2019-

3.RLTS.T163807A137392306.en. Downloaded on 10 February 2021

Dow, R.A. 2019c. Coeliccia membranipes. The IUCN Red List of Threatened Species 2019: e.T122883843A123029783.

https://dx.doi.org/10.2305/IUCN.UK.20192.RLTS.T122883843A123029783.en. Downloaded on 10 February 2021.

Dow, R.A. 2020a. Nepogomphus fruhstorferi. The IUCN Red List of Threatened Species 2020: e.T139369530A139404028.

https://dx.doi.org/10.2305/IUCN.UK.20201.RLTS.T139369530A139404028.en. Downloaded on 10 February 2021.

Dow, R.A. 2020b. Trithemis festiva. The IUCN Red List of Threatened Species 2020: e.T163609A140604365. https://dx.doi.org/10.2305/IUCN.UK.20203.RLTS.T163609A 140604365.en. Downloaded on 10 February 2021.

Dow, R.A. 2020c. Zygonyx ida (amended version of 2011 assessment). The IUCN Red List of Threatened Species 2020: e.T190852A177350096. https://dx.doi.org/10.2305/IUCN.UK.20203.RLTS.T190852A177350096.en. Downloaded on 10 February 2021.

Gunther, A. 2019. Rhinocypha anisoptera. The IUCN Red List of Threatened Species 2019: e.T122801676A122802882.

https://dx.doi.org/10.2305/IUCN.UK.20193.RLTS.T122801676A122802882.en. Downloaded on 10 February 2021.
Hanum, Silvy Olivia Salmah, S. D. (2013). Jenis-jenis Capung (Odonata) di Kawasan Taman Satwa Kandi Kota Sawahlunto, Sumatera Barat. Jurnal Biologi Universitas Andalas, 2 (1)(ISSN : 2303-2162), 71-76. https://doi.org/https://doi.org/10.25077/jbioua.2. $1 . \% 25$ p.2013

Hartika W., Farah D., Dan Wahdina. (2017). Keanekaragaman Jenis Capung (Odonata) Pada Ruang Terbuka Hijau Kota Pontianak. Jurnal Hutan Lestari, 5(2), 156-163.

Herlambang, A. E. N., Hadi, M., \& Tarwotjo, U. (2016). Struktur Komunitas Capung di Kawasan Wisata Curug Lawe Benowo Ungaran Barat. Bioma: Berkala Ilmiah Biologi, 18(2), 70. https://doi.org/10.14710/bioma.18.2.70-78

Hobson, K. A., Anderson, R. C., Soto, D. X., \& Wassenaar, L. I. (2012). Isotopic evidence that dragonflies (Pantala flavescens) migrating through the Maldives come from the northern Indian subcontinent. PloS one, $\quad 7(12), \quad 1-4$. https://doi.org/10.1371/journal.pone.0052594.

Kalkman, V. J., \& Orr, A. G. (2015). Brachytron (Issue June 2013). Field Guide to the damselfies of New Guinea. https://www.brachytron.nl/wpcontent/uploads/2018/03/Download-Fieldguidedragonflies-NewGuinea-20 15.pdf

Laily, Z., Rifqiyati, N., Kurniawan, A. (2018). Keanekaragaman Odonata pada Habitat Perairan dan Padang Rumput di Telaga Madirda. Jurnal MIPA 41(2), 105-110. https://doi.org/https://journal.unnes.ac.id/nju/ind ex.php/JM/article/view/19211

Lino, J., Koneri, R., \& Butarbutar, R. R. (2019). Keanekaragaman Capung (Odonata ) Di Tepi Sungai Kali a Jurusan. Jurnal MIPA Unsrat Online, $8(2)$, 59-62. Retrieved from http://ejournal.unsrat.ac.id/index.php/jmuo\%oAKe anekaragaman.

Low, V. L., Rashid, N. Y., Yusoff, A., Siow, V.W. Y., Prakash, B. K., Tan, T. K., Noorhidayah, M., Chen, C.H \& \& Azirun, S. M. (2017). Pleistocene demographic expansion and high gene flow in the Globe Skimmer dragonfly Pantala flavescens Fabricius (Odonata: Libellulidae) in Peninsular Malaysia. Zoologischer Anzeiger, 266, 23-27. https://doi.org/10.1016/j.jcz.2016.10.002.

Mitra, A. 2020. Orthetrum sabina. The IUCN Red List of Threatened Species 2020: e.T165470A83377025.https://dx.doi.org/10.2305/I UCN.UK.20201.RLTS.T165470A83377025.en Downloaded on 10 February 2021

Nugrahani, M. P. Nazar, L. Makitan, T. \& Setiyono, J. (2014). Peluit Tanda Bahaya: Capung Indikator Lingkungan Panduan Penilaian Kualitas Lingkungan Melalui Capung. Yogyakarta: Indonesia Dragonfly Society.

Orr, A. G. 2005. Dragonflies of Peninsular Malaysia and Singapore. Malaysia: Natural Histori Publications (Borneo).

Pamungkas, B. C. (2016). UNTRING: Dragonflies of Banyuwangi. Yogyakarta: Indonesian Dragonfly Society.

Rahmawati, L., Fajri, S. R., \& Armiani, S. (2019). Keanekaragaman Capung Jarum (Zygoptera) Di Taman Wisata Alam Kerandangan Batu Layar Kabupaten Lombok Barat. Bioscientist : Jurnal Ilmiah Biologi,

$7(1)$

16. 
https://doi.org/10.33394/bjib.v7i1.2381.

Rizal, S., \& Hadi, M. (2015). Inventarisasi Jenis Capung (Odonata) Pada Areal Persawahan Di Desa Pundenarum Kecamatan Karangawen Kabupaten Demak. Bioma: Berkala Ilmiah Biologi, 17(1), 16. https://doi.org/10.14710/bioma.17.1.16-20.

Rokhaman, E., Setyawati, S.M \& Hidayat, S. 2020. Biodiversitas Capung Subordo Anisoptera Di Sekitar Aliran Sungai Muria Desa Colo Kudus. Journal of Biology Education. 3(1): 1-10.

Setiyono J, Diniarsi S, Oscilata ENR \& Budi NS.(2017). Dragonfly of Yogyakarta. Yogyakarta:Indonesia Dragonfly Society.

Sharma, G. 2010. Orthetrum pruinosum. The IUCN Red List of Threatened Species 2010: e.T167097A6301540. https://dx.doi.org/10.2305/IUCN.UK.2010-

4.RLTS.T167097A6301540.en. Downloaded on 10 February 2021.

Silva, D. P., Marco, P. De \& Resende, D.C. (2010). Adult Odonste Abundance and Community Assemblage Measures as Indicators of Stream Ecological
Integrity: A Case Study. Ecological indicator. 10: 744752. https://doi.org/10.1016/j.ecolind.2009.12.004

Suaskara, I. B., \& Joni, M. (2020). Keanekaragaman Jenis Capung Dan Pemanfaatan Nimfanya Sebagai Nilai Tambah Pendapatan Di Bendungan Latu Abiansemal. Simbiosis, $\quad 8(1), \quad 28$. https://doi.org/10.24843/jsimbiosis.2020.v08.io 1.p 04

Subramanian, K.A. 2020. Diplacodes trivialis. The IUCN Red List of Threatened Species 2020: e.T167372A8337 1487. https://dx.doi.org/10.2305/IUCN.UK.20201.RLTS.T167372A83371487.en. Downloaded on 10 February 2021.

Soendjoto, M. A. (2016). Capung, predator cantik penghuni perairan. Warta Konservasi Lahan Basah, 24(1),

13-18. 